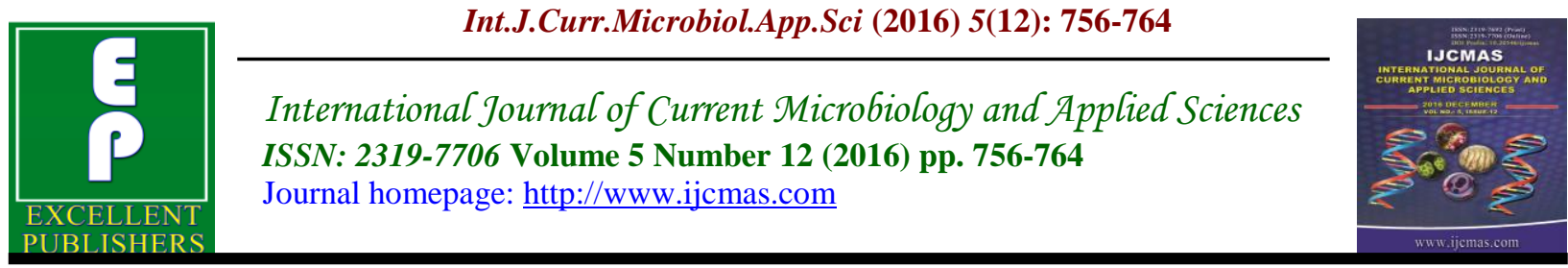

Original Research Article

http://dx.doi.org/10.20546/ijcmas.2016.512.086

\title{
Growth of Botryodiplodia theobromae an Incitant of Longitudinal Splitting of Bark and Wood Disease in Acidlime (Citrus aurantifolia Swingle) as Influenced by pH Levels, Temperature and Growth Media
}

\author{
T. Gouri Sankar ${ }^{1}$, V. Gopi ${ }^{1}$, Y. Hema Bharathi ${ }^{1}$, K. Gopal ${ }^{2 *}$ and \\ L. Mukunda Lakshmi ${ }^{1}$ \\ ${ }^{1}$ Molecular Diagnosis Laboratory, Citrus Research Station, Dr. Y.S.R. Horticultural University, \\ Tirupati - 517 502, Andhra Pradesh, India \\ ${ }^{2}$ College of Horticulture, Dr. Y.S.R. Horticultural University, Anantharajupeta - 516105 , \\ Andhra Pradesh, India \\ *Corresponding author
}

A B S T R A C T

Keywords

Botryodiplodia theobromae,

Longitudinal

Splitting of Bark and Wood Disease (LSPWD), Growth.

Article Info

Accepted:

26 November 2016

Available Online:

10 December 2016
Studies on effect of $\mathrm{pH}$ levels, temperature and growth media on growth of Botryodiplodia theobromae causing longitudinal splitting of bark and wood disease on acid lime revealed that higher dry mycelial weight of the fungus was obtained at 25 to $30^{\circ} \mathrm{C}$ which was considered as optimum for the vegetative growth. Among the different media tested Potato Dextrose Broth (PDB) supported for maximum dry mycelial weight followed by Richards Broth (RB), Czapek Dox Broth (CPB) and Czapek Dox Broth (CDB) medium. Among the different media used PDB gave maximum dry mycelial weight at $\mathrm{pH}$ ranged from 5.0 to 6.0 followed by $\mathrm{CPB}, \mathrm{CDB}$ and $\mathrm{RB}$ media.

\section{Introduction}

Citrus is one of the most important fruit crop grown throughout the world. Citrus is grown in more than 50 countries of the world and it is one of the choicest fruits having highest consumer's preference both as fresh fruits as well as for its refreshing processed juice. Citrus is the third most important fruit crop of India after banana and mango. The most important citrus cultivars in India are the mandarins (Citrus reticulata Blanco), sweet orange (Citrus sinensis Osbeck) and acidlime (Citrus aurantifolia Swingle). Collectively citrus fruit in India have an estimated production of 3.79 million tonnes from an area of 0.45 million hectors.

Acid lime is one of the important citrus fruit grown over an area of $0.90 \mathrm{~m}$ ha and constitute nearly 20 per cent of the total citrus production of $90.75 \mathrm{mt}$ in India. Andhra Pradesh, Maharashtra, Karnataka, Punjab, and Assam are the leading acid lime growing states. A.P occupies the first place 
both in area (2.02 lakhs ha) and production $(13.50 \mathrm{MT})$ of limes followed by Maharashtra.

Among the diseases responsible for acid lime decline, the bark and wood splitting disease is one of the major factor affecting both life and production under field conditions (Gopal et al., 2000). The disease is seen on almost all the acid lime clones/varieties both in farmers orchards and in the Research station. The proportion of the disease is reported to be up to 15 per cent in farmer's orchards (Gopal et al., 2005).

The infected plant shows internal discoloration and darkening of the bark of infected twigs. Ash coloured discoloration of vascular tissues are also seen on splitting the twigs/branches. In early stages, epidermal and sub-epidermal cells of twigs and branches appear slightly shriveled (Gopal et al., 2005). Keeping the importance and the severity of the disease, in present studies, emphasis was given to investigate the growth requirements to the pathogen.

\section{Materials and Methods}

\section{Collection and isolation of pathogen from diseased acidlime plants}

The infected bark and wood samples were collected from the acidlime trees at Citrus Research Station, Tirupati, Chittoor District, A.P. For isolating the pathogen, 2 to $3 \mathrm{~mm}$ long bits were cut from the bark portion of the affected acidlime plants, which showed apparently dark brown discoloration of the bark longitudinally rectangular, starting from base of the trunk. The bits were treated with $0.1 \% \mathrm{HgCl}_{2}$ for 30 seconds followed by three washings with sterile distilled water. The bits were transferred to another Petri plate containing sterile discs of blotting paper. The dried bits were subsequently transferred to the slants of PDA under aseptic condition and incubated at $25 \pm 1^{\circ} \mathrm{C}$. Subculturing was done on medium whenever required.

\section{Growth of B. theobromae on different solid media}

Four solid media viz., Potato Dextrose Agar, Richards Agar (RA), Carrot Potato Agar (CPA) and Czapek's Dox Agar (CDA) media were used to assess the growth etc. for the isolates of the pathogen (Fig.1).

Mycelial disc of $20 \mathrm{~mm}$ diameter was cut with sterilized cork borer from the periphery of an actively growing three days old culture of the fungus grown on PDA, RA, CPA and CDA medium and transferred aseptically to the centre of each plate. Each isolate was replicated twice and the plates were incubated at $28 \pm 2^{\circ} \mathrm{C}$.

For determining the variation among different isolates of Botryodiplodia theobromae in terms of colony diameter, colony growth of the fungus in each Petri plate was measured 3 days after inoculation. The colony growth was measured along two diameters at right angles and averaged. For growth rate, colony growth in $\mathrm{mm}$ per day was measured.

\section{Effect of different temperatures on growth and sporulation of $B$. theobromae in liquid media}

To determine optimum temperature for growth and sporulation of the test fungus, the fungus was distributed in different flasks containing $25 \mathrm{ml}$ of medium in each. Then the flasks were incubated at different temperatures viz., $10,20,30$ and $40^{\circ} \mathrm{C}$ for recording observations up to 14 days. The data in terms of dry weight of the fungal 
vegetative growth as well as extent of sporulation were recorded.

Effect of different hydrogen ion concentration on the growth and sporulation of $B$. theobromae in liquid media

In order to study the effect of different hydrogen ion concentrations on growth, production of conidia, $\mathrm{pH}$ levels viz., 3.0, 4.0, 5.0, 6.0 and 9.0 were adjusted in basal medium with the help of BDH narrow range $\mathrm{pH}$ paper using $\mathrm{N} / 10 \mathrm{NaOH}$ or $\mathrm{HCl}$. The flasks containing $25 \mathrm{ml}$ of the basal medium adjusted to different $\mathrm{pH}$ levels were autoclaved, incubated at $25 \pm 1^{\circ} \mathrm{c}$. The data in terms of mycelial dry weight and sporulation were recorded after 14 days.

\section{Results and Discussion}

Twelve isolates of the pathogen namely LBWP-1, LBWP-2, LBWP-3, LBWP-4, LBWP-5, LBWP-6, LBWP-7, LBWP-8, LBWP-9, LBWP-10, LBWP-11, and LBWP-12 were obtained from infected samples of acidlime plants with longitudinal splitting of bark and wood disease (LBWSP) and named accordingly. These isolates were used in the present investigation.

\section{Growth on solid media}

The isolates of $B$. theobromae were grown on the four solid media at $28 \pm 2^{\circ} \mathrm{C}$ for 2 days. A significant variation was noticed among the isolates of $B$. theobromae with respect to colony growth, mycelia characters and growth rate and chlamydospores production on different solid media. The colony growth of 12 isolates on different solid media are presented in Tables 1 . The growth rate of $B$. theobromae depending on the growth rate on solid medium, all isolates of $B$. theobromae were categorized into three groups viz., fast, medium and slow growing isolates. The colonies of isolates which grew 40-82 $\mathrm{mm}$ in diameter within 72 $\mathrm{h}$ of incubation were categorized as slow growing isolates and the isolates whose colonies grew 40 to $82 \mathrm{~mm}$ in diameter with in $48 \mathrm{~h}$ of incubation were categorized as medium growing, where as the colonies which grew 40 to $82 \mathrm{~mm}$ in diameter within $24 \mathrm{~h}$ of incubation were categorized as fast growing isolates.

The isolates LBWP-1, LBWP-6, LBWP-7, LBWP-8, LBWP-10 and LBWP-12 are medium growing where as LBWP-2, LBWP-3, LBWP-4, LBWP-5, LBWP-9 and LBWP-11 are slow growing, whereas on CDA medium all the isolates are showing slow growth rate (Table 1).

In case of RA medium, the isolates LBWP1, LBWP-2, LBWP-5 and LBWP-7 are medium growing where as LBWP-3, LBWP-4, LBWP-6, LBWP-8, LBWP-9, LBWP-10, LBWP-11 and LBWP-12 are slow growing isolates (Table 1). The isolates LBWP-1, LBWP-5, LBWP-7, LBWP-10, LBWP-11, and LBWP-12, are medium growing where as LBWP-2, LBWP-3, LBWP-4, LBWP-7, LBWP-9, are slow growing isolates in case of CPA medium (Table 1). In all the four media used none of the isolate has shown fast growth.

In present investigation most of the isolates have showed slow to medium growth rate. However, no isolate showed fast growth which confirmed that the pathogen is slow growing organism. Among the different media tested for their growth rate, CPA medium was observed to be the best which supported for maximum growth of different isolates of pathogen followed by PDA. However, on CDA and RA media, all the isolates have showed least growth rate.

Similar studies were carried out by Ram (1993) and observed variation in the size of conidia, vegetative growth and sporulation. 
Spore size was generally similar in all isolates, but spores were smaller in isolates from mango. Vegetative growth rate, mycelial dry weight and sporulation in coconut isolates were lower on all the media tested compared with isolates from other hosts. Chowdhury et al., (1987) studied the morphology of different $B$. theobromae isolates interms of growth on PDA, aerial mycelium, conidial size and pycnidial status in 6 crops from 5 countries. Almeida et al., (2001) studied morphological characteristics of a strain 715 of $B$. theobrmae, a causal agent of plant and fruit rots, and observed production of jasmonic acid, by using CPA and PDA.

Effect of different temperatures on growth of Botryodiplodia theobromae

It is evident from table 2 that the maximum mycelial dry weight of $680 \mathrm{mg}$ was at $30^{\circ} \mathrm{C}$ followed by mycelial dry weight $(560 \mathrm{mg})$ at $25^{\circ} \mathrm{C}$ and $(450 \mathrm{mg})$ at $20^{\circ} \mathrm{C}$. The least dry weight of $370 \mathrm{mg}$ was recorded at $40^{\circ} \mathrm{C}$ in $\mathrm{PDB}$ medium. In $\mathrm{CDB}$, the maximum mycelial dry weight of $370 \mathrm{mg}$ was at $30^{\circ} \mathrm{C}$ followed by $(350 \mathrm{mg})$ at $40^{\circ} \mathrm{C}$ and $(220 \mathrm{mg})$ at $20^{\circ} \mathrm{C}$. The least mycelial dry weight $(200$ $\mathrm{mg}$ ) was recorded at $25^{\circ} \mathrm{C}$.

In $\mathrm{RB}$ the maximum mycelial dry weight was $(640 \mathrm{mg})$ at $30^{\circ} \mathrm{C}$ followed by $40^{\circ} \mathrm{C}(420$ $\mathrm{mg})$ and $25^{\circ} \mathrm{C}(400 \mathrm{mg})$. The least mycelial dry weight was observed at $20^{\circ} \mathrm{C}(390 \mathrm{mg})$. In $\mathrm{CPB}$ the maximum mycelial dry weight of $510 \mathrm{mg}$ at $30^{\circ} \mathrm{C}$ followed by $25^{\circ} \mathrm{C}(460$ $\mathrm{mg})$ and $(450 \mathrm{mg})$ in $20^{\circ} \mathrm{C}$. The least mycelial dry weight was observed at $40^{\circ} \mathrm{C}$ (330 mg) (Table 2, Fig.2).

In present study, higher dry mycelial weight of the fungus was obtained at 25 to $30^{\circ} \mathrm{C}$ which was considered as optimum for the vegetative growth. Least dry weight was obtained at $40^{\circ} \mathrm{C}$. Among the different media tested PDB supported for maximum dry mycelial weight followed by $\mathrm{RB}, \mathrm{CPB}$ and CDB medium.

\section{Effect of different pH levels on growth of Bortyodiplodia theobromae}

The maximum mycelial dry weight $(510 \mathrm{mg})$ was at $\mathrm{pH} 6$ followed by $\mathrm{pH} 5$ (440 mg) and pH 7 (410 mg) and they were on par with each other. The fungus did not grew at $\mathrm{pH} 3$ and $\mathrm{pH} 4$ in $\mathrm{PDB}$. In $\mathrm{CDB}$ the maximum mycelial dry weight of $400 \mathrm{mg}$ was at $\mathrm{pH} 6$ followed by $\mathrm{pH} 5(310 \mathrm{mg})$ and $\mathrm{pH} 7$ (310 $\mathrm{mg})$. Further, there was no growth at $\mathrm{pH} 3$ and 4 (Table 3, Fig.3).

In $\mathrm{RB}$ the maximum mycelial dry weight of $350 \mathrm{mg}$ was at $\mathrm{pH} 6$ followed by $\mathrm{pH}$ 7(320 $\mathrm{mg})$. The least mycelial dry weight was recorded at $\mathrm{pH} 5(210 \mathrm{mg})$. There was no growth at $\mathrm{pH} 3$ and 4 . In CPB the maximum mycelial dry weight of $460 \mathrm{mg}$ was at $\mathrm{pH} 7$ followed by $\mathrm{pH} 6$ (440 mg). The least mycelial dry weight of $400 \mathrm{mg}$ was at $\mathrm{pH} 5$. No growth of isolates was observed in the broth's pH 3 and pH 4.

The hydrogen ion concentration had marked influence on growth of the fungus. The fungus grew best at $\mathrm{pH} 6.0$ followed by $\mathrm{pH}$ 5.0. Hence, the optimum $\mathrm{pH}$ for the growth of this fungus was 5.0 to 6.0. No growth was observed at $\mathrm{pH} 3.0$ and 4.0.

More or less similar opinion was expressed by Pati et al., (2001) and who studied the effect of temperature and $\mathrm{pH}$ on growth of Botryodiplodia theobromae causing Java black rot of sweet potato tubers. The optimum temperature which favoured the growth of $B$. theobromae was between 25 and $30^{\circ} \mathrm{C}$, while the optimum $\mathrm{pH}$ required for growth was in the range of 5.0-6.0. 
Table.1 Growth of B. theobromae isolates on different growth media

\begin{tabular}{|c|c|c|c|c|c|c|c|c|}
\hline \multirow[t]{2}{*}{ Isolate } & \multicolumn{2}{|c|}{ PDA medium } & \multicolumn{2}{|c|}{ CDA medium } & \multicolumn{2}{|c|}{ RA medium } & \multicolumn{2}{|c|}{ CPA medium } \\
\hline & $\begin{array}{c}\text { Colony } \\
\text { diameter }(\mathrm{mm})\end{array}$ & $\begin{array}{l}\text { Growth } \\
\text { rate }\end{array}$ & $\begin{array}{c}\text { Colony } \\
\text { diameter }(\mathrm{mm})\end{array}$ & $\begin{array}{c}\text { Growth } \\
\text { rate }\end{array}$ & $\begin{array}{c}\text { Colony } \\
\text { diameter }(\mathrm{mm})\end{array}$ & $\begin{array}{c}\text { Growth } \\
\text { rate }\end{array}$ & $\begin{array}{c}\text { Colony } \\
\text { diameter }(\mathrm{mm})\end{array}$ & $\begin{array}{c}\text { Growth } \\
\text { rate }\end{array}$ \\
\hline LBWP-1 & 82.0 & Medium & 81.6 & Slow & 82.0 & Medium & 82.0 & Medium \\
\hline LBWP-2 & 80.0 & Slow & 79.2 & Slow & 79.8 & Medium & 82.0 & Slow \\
\hline LBWP-3 & 80.6 & Slow & 80.6 & Slow & 79.8 & Slow & 80.6 & Slow \\
\hline LBWP-4 & 81.6 & Slow & 80.4 & Slow & 78.8 & Slow & 81.8 & Slow \\
\hline LBWP-5 & 81.4 & Slow & 81.6 & Slow & 81.0 & Medium & 82.0 & Medium \\
\hline LBWP-6 & 82.0 & Medium & 82.0 & Slow & 82.0 & Slow & 82.0 & Slow \\
\hline LBWP-7 & 82.0 & Medium & 82.0 & Slow & 82.0 & Medium & 82.0 & Medium \\
\hline LBWP-8 & 82.0 & Medium & 82.0 & Slow & 82.0 & Slow & 82.0 & Slow \\
\hline LBWP-9 & 82.0 & Slow & 82.0 & Slow & 81.4 & Slow & 82.0 & Slow \\
\hline LBWP-10 & 82.0 & Medium & 82.0 & Slow & 82.0 & Slow & 82.0 & Medium \\
\hline LBWP-11 & 80.7 & Slow & 82.0 & Slow & 81.8 & Slow & 82.0 & Medium \\
\hline LBWP-12 & 82.0 & Medium & 82.0 & Slow & 81.6 & Slow & 82.0 & Medium \\
\hline $\mathrm{CD}(0.05)$ & 0.5209 & -- & 0.6230 & -- & 0.6230 & & 0.2176 & \\
\hline
\end{tabular}


Table.2 Effect of different temperature levels on $B$. theobromae growth on different growth media (in $\mathrm{mg}$ )

\begin{tabular}{|c|c|c|c|c|}
\hline Temperature & PDB & CDB & RB & CPB \\
\hline $\mathbf{2 0}^{\mathbf{C}}$ & 450 & 220 & 390 & 450 \\
\hline $\mathbf{2 5}^{\mathbf{C}} \mathbf{C}$ & 560 & 200 & 400 & 460 \\
\hline $\mathbf{3 0}^{\mathbf{0}} \mathbf{C}$ & 680 & 370 & 640 & 510 \\
\hline $\mathbf{4 0}^{\mathbf{C}} \mathbf{C}$ & 370 & 350 & 420 & 330 \\
\hline $\mathbf{C D}(\mathbf{. 0 5})$ & 2.03 & 1.88 & 2.88 & 1.88 \\
\hline
\end{tabular}

$\begin{array}{ll}\mathrm{PDB}= & \text { Potato Dextrose Broth } \\ \mathrm{CDB}= & \text { Czapek Dox Broth } \\ \mathrm{RB}= & \text { Richards Broth } \\ \mathrm{CPB}= & \text { Carrot Potato Broth }\end{array}$

Table.3 Effect of different $\mathrm{pH}$ levels on B. theobromae grown on different growth

\begin{tabular}{|c|c|c|c|c|}
\hline $\mathbf{p H}$ & PDB & CDB & RB & CPB \\
\hline $\mathbf{7 . 0}$ & 410 & 310 & 320 & 460 \\
\hline $\mathbf{6 . 0}$ & 510 & 400 & 350 & 440 \\
\hline $\mathbf{5 . 0}$ & 440 & 310 & 210 & 400 \\
\hline $\mathbf{4 . 0}$ & 0 & 0 & 0 & 0 \\
\hline $\mathbf{3 . 0}$ & 0 & 0 & 0 & 0 \\
\hline CD (.05) & 2.82 & 2.44 & 1.56 & 3.13 \\
\hline
\end{tabular}

$\mathrm{PDB}=$ Potato Dextrose Broth

$\mathrm{CDB}=$ Czapek Dox Broth

$\mathrm{RB}=$ Richards Broth

$\mathrm{CPB}=$ Carrot Potato Broth 
Fig.1 Colony morphology of Botryodiplodia theobromae on different solid media

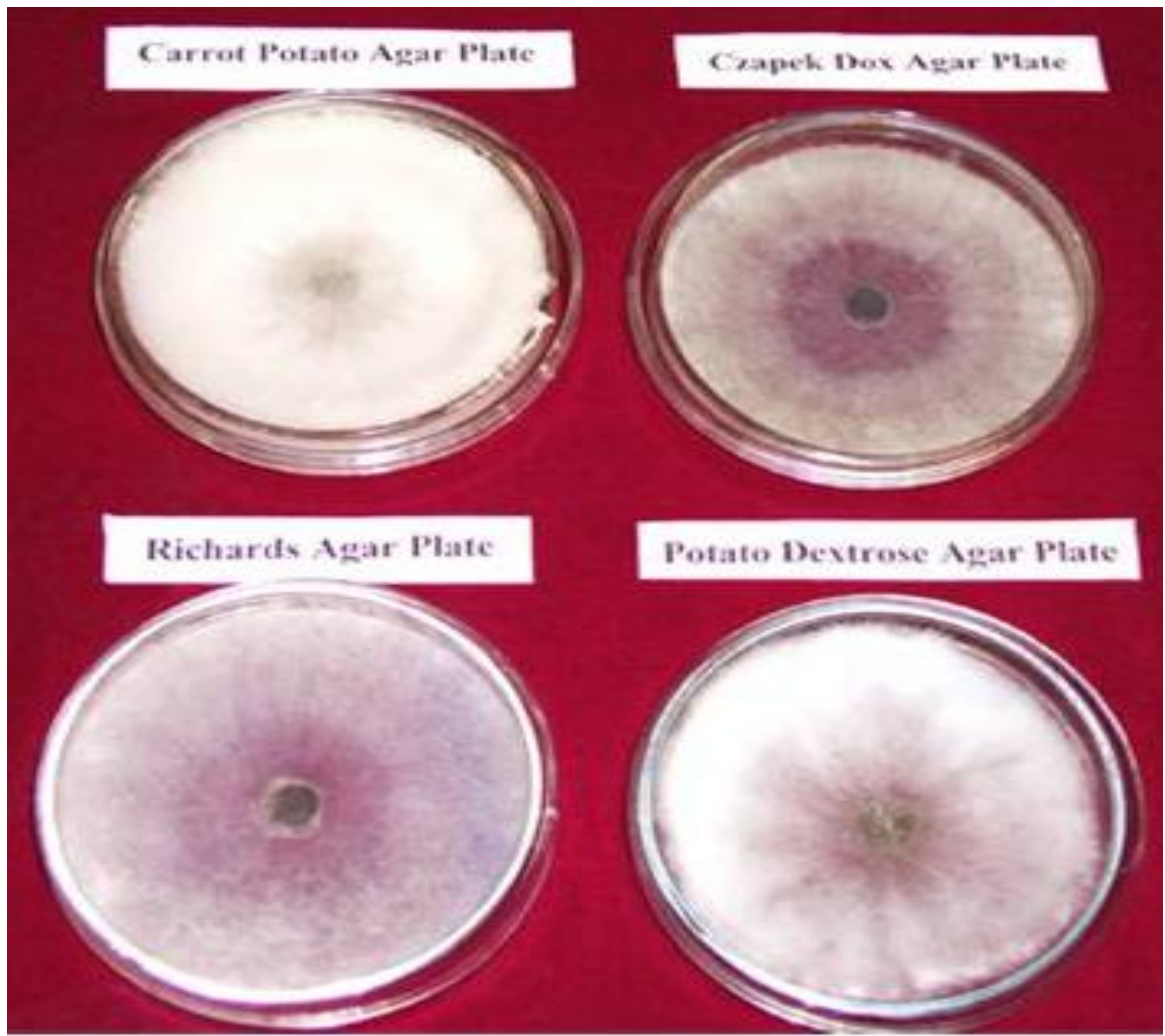

Fig.2 Effect of different temperature levels on grwth of B.theobromae in (A) Richards broth (B) Carrot potato broth (C) Potato dextrose broth (D) Czapek dox broth
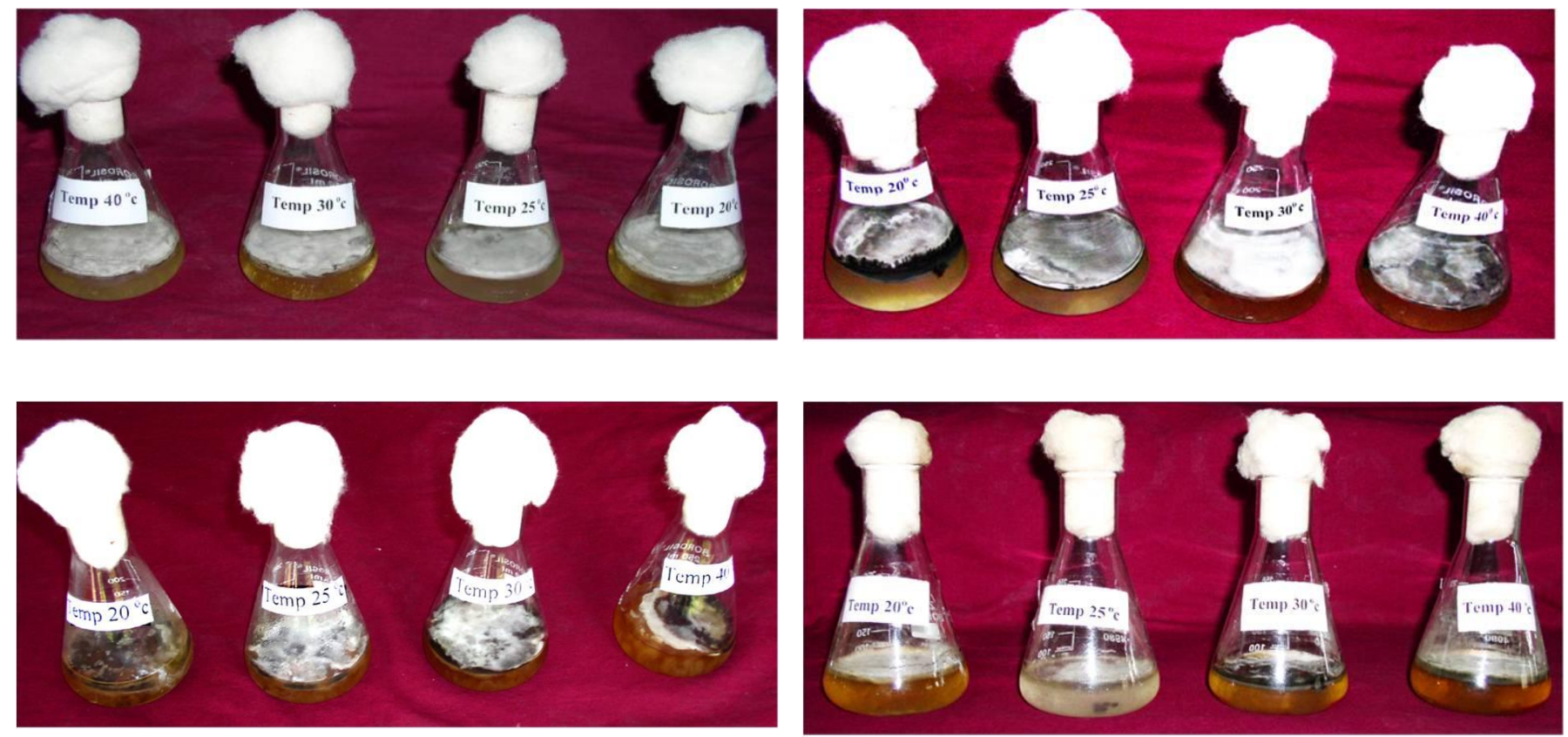
Fig.3 Effect of different pH levels on growth of B.theobromae in (A) Potato dextrose broth (B) Czapek dox broth (C) Richards broth

(D) Carrot potato broth
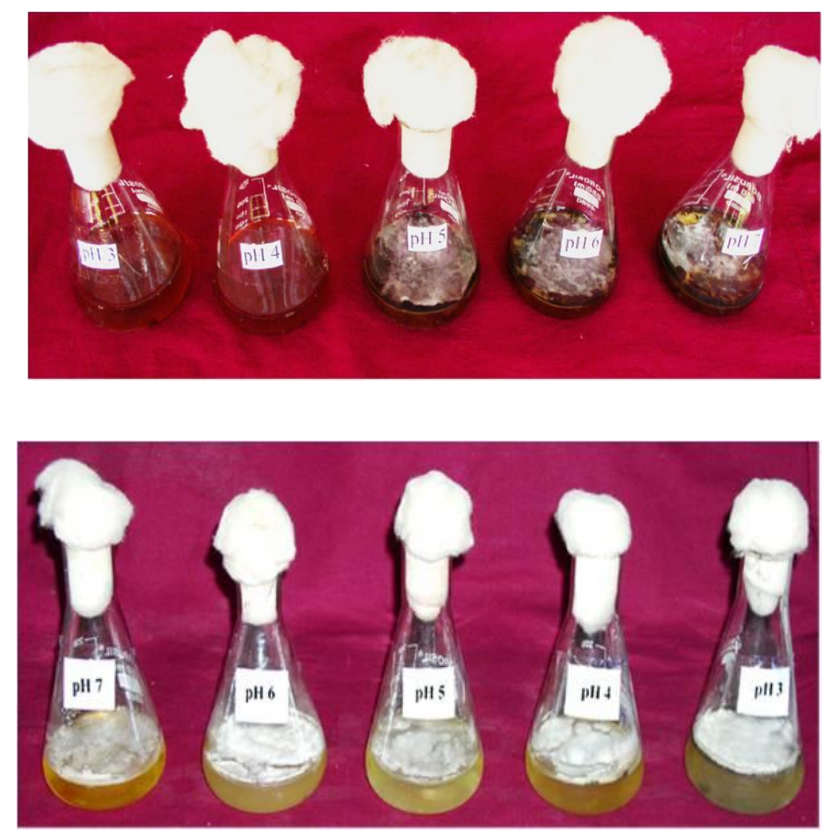

Eng et al., (2003) studied effect of temperature and $\mathrm{pH}$ on colony growth of Botryodiplodia theobromae both temperature and culture medium influenced the growth density, but radial velocity of growth was affected by temperature above $40^{\circ} \mathrm{C}$. In addition, initial $\mathrm{pH}$ of culture media did not affect either parameter.

Sabet et al., (1995) observed the factors affecting severity of $B$. theobromae on date palm cv. Zaghlol off-shoot and its control. The optimum temperature for infection by the fungus was ranged from 30 to $35^{\circ} \mathrm{C}$ at $50 \%$ RH. Propiconazole was the best fungicide to inhibit the linear growth of the pathogen and to eliminate new infections in the field. Mali et al., (1987) has given the methods of inoculation, temperature and humidity in relation to rotting of corm of elephant foot yam (Amorphophallus campanulatus Blume) by Botryodiplodia
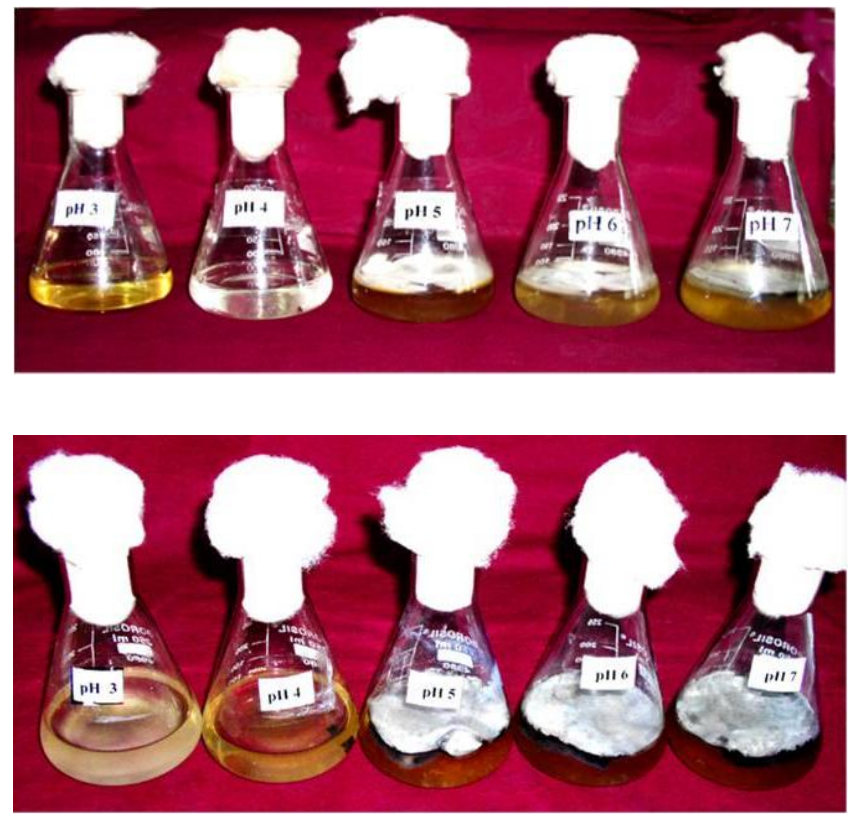

theobromae. In inoculation experiments, corm developed rotting only when inoculum placed within the pulp and surface inoculated corms remained healthy. Rotting was initially slow but increased after 1 month. Maximum rotting occurred at $30^{\circ} \mathrm{C}$ and none occurred at 10 or $40^{\circ} \mathrm{C}$. High RH $(85-90 \%)$ has contributed to maximum rotting where as none occurred at low temperature with high $\mathrm{RH}$ or at room temperature with low $\mathrm{RH}$.

\section{References}

Almedia, G., Michelena, G. and Altuna, B. 2001. Microbiological characteristics of Botryodiplodia theobromae culture in aerobic and anaerobic conditions. Revista -ICIDCA-Sobre-losDerivados-de-la-cana-de-Azucar, 35(1): 9.

Chowdhury, N., Mathur, S.B. and 
Neergaurd, P. 1987. Studies on the morphology of different Botryodiplodia theobromae isolates. Bangladesh J. Agri., 12(2):139-141.

Eng, F., Gutierrez Rojas, M. and Favela Torres, E. 2003. A survey of temperature and $\mathrm{pH}$ effect on colonial growth of Botryodiplodia theobromae RC1. Revista - Iberoamericana-deMicologia, 20(4):172-175.

Gopal, K., Subbi Reddy, G., Reddy, M.R.S., Chenchu Reddy, B., Rama Krishna Rao, A., Madhavi, M. and Venkataramana, K.T. 2000. Citrus decline in Andhra Pradesh, causes and their management. pp. 709-718 In: Syam Singh, Ghosh SP, eds, Hi-Tech Citrus Management Indian Society of Citriculture, Nagpur and Indian Council of Agricultural Research, New Delhi.

Gopal, K., Suresh, M., Gopi, V., Sreenivasulu, Y., Khayum Ahemmed, S. and Sivakumar, N. 2005. First Report on Etiology and Management of Bark and Wood Splitting Disease in Acidlime from Andhra Pradesh. Paper presented in Ind Global Conference, organized by Indian Society of Mycology and Plant Pathology, MPUAT, Udaipur. $25^{\text {th }}$ to $29^{\text {th }}$
November.

Mali, B.L. and Bhatnagar, M.K. 1987. Methods of inoculation, temperature and humidity in relation to rotting of corn of elephant foot yam (Amorphophallus campanulatus blume) by Botyodiplodia theobromae. Indian J. Mycol. Plant Pathol., 17(2): 229-230.

Pati, S.P., Maheswari, S.K. and Ray, R.C. 2001. Effect of culture media, temperature, $\mathrm{pH}$, carbon and nitrogen sources on growth of Botryodiplodia theobromae causing Java black rot of sweet potato tubers. J. Mycopathol. Res., 39(1): 15-19.

Ram, C. 1993. Cultural characteristics, sporulations and virulence of Botryodiplodia theobromae "strains" a causal agent of leaf blight of coconut palm (Cocus nucifera). Fitopathologica-Brasileira, 1(2): 143146.

Sabet, K.K., Hussien, S.A., Barakat, M.F. and Rashed, F. 1995. Factors affecting severity of Botryodiplodia theobromae on date palm off-shoot and its control. Egyptian J. Agri. Res., 73(4): 925-933.

\section{How to cite this article:}

Gouri Sankar, T., V. Gopi, Y. Hema Bharathi, K. Gopal and L. Mukunda Lakshmi. 2016. Growth of Botryodiplodia theobromae an Incitant of Longitudinal Splitting of Bark and Wood Disease in Acidlime (Citrus aurantifolia Swingle) as Influenced by $\mathrm{pH}$ Levels, Temperature and Growth Media. Int.J.Curr.Microbiol.App.Sci. 5(12): 756-764. doi: http://dx.doi.org/10.20546/ijcmas.2016.512.086 